Kinestetik : Jurnal Imiah Pendidikan Jasmani 5 (1) (2021)

Kinestetik : Jurnal Imiah Pendidikan Jasmani

https://ejournal.unib.ac.id/index.php/kinestetik/index

DOI : 10.33369/jk.v5i1.12796

\title{
IDENTIFICATION OF FRESH CARDIORESPIRATION OF 2018 NUSA CENDANA UNIVERSITY OF PENJASKESREK STUDENTS DURING COVID-19
}

\author{
Yudabbirul arif ${ }^{\prime}$, Lukas M Boleng ${ }^{2}$, Michael J. H. Louk ${ }^{3}$, Ronald Dwi A Fufu ${ }^{4}$ \\ ${ }^{1234}$ Penjaskesrek, FKIP, Universitas Nusa Cendana, Kupang, Indonesia
}

\section{Article Info}

Article History :

Received : October 2020

Revised : December 2020

Accepted : March 2021

Available online : March 2021

\section{Keywords:}

Cardiorespiratory, Bleep test.

\begin{abstract}
During the pandemic, online lectures are mandatory however, how can students' physical activity be maintained or not. The goal is that students who have good cardiorespiratory freshness are expected to have good endurance. This research is a qualitative descriptive study. The method used is a survey with data collection techniques using measurement tests. The instrument used to determine the endurance level of a student's physical fitness was a multi-stage running test or the bleep test. The sample in this study using simple random sampling, the research sample was selected as many as 30 students. The results of the data from 30 Penjaskesrek class 2018 Nusa Cendana University students who took the multistage fitness test to find out the level of cardiorespiratory freshness was in the very poor classification of 10 people with a percentage of $33.33 \%$, the lack of classification was 3 people (10\%), the classification is quite good (33.33\%), good classification 5 people (16.66\%), very good classification 2 people $(6.66 \%)$, and no student is in the special classification $(0 \%)$. The results show that the level of cardiorespiratory freshness The 2018 Nusa Cendana University Penjaskesrek students are in a sufficient classification.
\end{abstract}

Corresponding address : perum matani penfui, kupang, NTT

Email : yudabbirul@staf.undana.ac.id
ISSN 2685-6514 (online)

ISSN 2477-331X (print) 


\section{INTRODUCTION}

At this time, the phenomenon that is currently occurring in a new lifestyle, as we understand it about healthy living, maintaining distance, and so on, can be called a new normal, the main cause is the coronavirus.

This virus is a type of virus that can be said to be new, so the vaccine is still being studied and has not been found. easy transmission and a very high-risk level so we need to be vigilant. There is, however, growing consensus that the pathogen is being readily transmitted among humans (Osler, 2019)

At this time the activities of the activities in the community changed as a whole. The most prominent changes can be seen in the aspects of life at all levels of society such as sports activities, economic activities, especially in the world of education. So there are many preventive efforts that you have to do, such as exercising to maintain endurance, wearing masks and washing your hands frequently, and so on, which are related to a healthy lifestyle. The trends will improve only if students are taught how to lead healthy lifestyles (Anderson \& Glover, 2017). For physical education the teacher must show the many ways in which physical education can have a positive impact on life.

If the body's fitness is not maintained, it will be very susceptible to viruses. For this reason, innovations are carried out in the world of education, namely by using online education (in the network), which is expected to emphasize the level of the spread of COVID-19. As an educator who adapts to technological advances, he must be able to use the facilities and infrastructure that have been provided through the zoom application, both in the world of sports and in the world of education itself.

A person who has a good level of cardiorespiratory freshness is expected to be able to do activities for a relatively long time and have the body's resistance to disease attacks so that their activities are not disturbed.

A person who has a good cardiorespiratory freshness level is expected to be able to carry out activities for a relatively long time and have the body's resistance to disease so that his activities are not disturbed. Healthrelated components of fitness include cardiorespiratory fitness, muscular strength, muscular endurance, and flexibility (Sullivan, 2015).

Strength is the basic ability of the condition components, because strength is the driving force of any physical activity (Arif, Boleng, Babang, et al., 2019). so it can be understood that good physical condition will increase the components of the student's body condition. Scaled to developmental appropriateness, the components of Health-Related Physical Fitness, cardiorespiratory endurance, muscular strength, muscular endur- ance, body composition, and flexibility (1) may be introduced in the early childhood years through an educational movement concept called Body Awareness (what the body can do) (H. Brewer, 2018). 
This will provide about the importance of sports education for students during the COVID -19 pandemic. Physical fitness has components consisting of several kinds and all of these elements must be met to be said to have good physical fitness. The components of health-related physical fitness are aerobic fitness, muscular strength, muscular endurance, flexibility, and body composition as they relate specifi- cally to health enhancement (Ayers \& Sariscsany, 2011).We can see from some of the components of physical fitness, lung and heart endurance or cardiorespiratory is the biggest contributor in improving and maintaining fitness or good health.

We need to realize that in choosing and doing sports activities, it must be adjusted to our abilities. Today's technological advances make it very easy for humans to get everything easier, one of which is by using the Zoom application. First, it is hoped that students will have good cardiorespiratory freshness when the Covi-19 Pandemic occurs.

Implementation can be interpreted as the expansion of activities that adjust in the interaction between goals and actions to achieve and require an effective and efficient bureaucratic implementing network. Despite the effectiveness of quality physical education (whereby students have an opportunity to learn meaningful content with appropriate instruction and assessments) in increasing physical activity, challenges exist to its equitable and effective delivery (Harold W. Kohl III, 2013).
Fitness good cardiorespiration will have a positive impact towards: (1) capacity building blood circulation and heart work; (2) increased strength, flexibility, endurance, coordination, balance, speed, and agility; (3) increased mobility efficiently; (4) increased ability restoration of organs after exercise; and (5) increased ability to respond with fast

Physical Best complements and supports existing physical education programs by teaching and applying health-related physical fitness concepts to promote lifelong physical activity (Ayers \& Sariscsany, 2011).

The new health consciousness intensified attention on the care of the body by awarding exercise a major role in the achievement and maintenance of health and happiness, to the point where physical fitness and body shape have increasingly been used by advertisers as cultural symbols of both wellbeing and wealth (Tinning, 2010). It can be understood that exercise awareness for health maintenance is for physical care as well. They've since experienced the incredible benefits weight training provides, such as increased muscle strength and endurance, stronger bones, definition, and leaner bodies (Arif, Boleng, Maria, et al., 2019). We can understand that if the body's activities are trained, the components of physical fitness from strength, endurance, and bone strength will increase.

Physical fitness is closely related to human activities in doing work and moving. In general, what is meant by physical fitness is physical fitness. Physical fitness is a person's ability to perform physical tasks that require 
strength, endurance, and flexibility (Bridge et al., 2014).

One of the factors that determine physical fitness is endurance, which is the main component that determines one's fitness. Endurance is the ability to sustain a dynamic effort over an extended period, lasting several minutes or even hours (Development \& Coaching, 2012). Endurance is the body's ability to carry out sustainable activities for a long time without significant fatigue.

States that physical fitness involves five components, namely: lung and heart endurance, muscle strength, muscle endurance, flexibility or flexibility, and body composition (Bridge et al., 2014).

However, in addition to being concerned about the function and control of muscle through the motor unit (the basic functional unit of the human neuromuscular system), the professional must be cognizant of how the cardiovascular and respiratory systems interact with the neuromuscular system to provide an optimal environment for sustaining muscular work (Lynn et al., 2018). We can understand that the cardio and respiratory systems interact with the neuromuscular system to optimize muscle work.

For example, the respiratory system brings oxygen into the body; the vascular system transports the oxygen in the blood, which is pumped by the cardiac muscle (hence cardiovascular) and is used in the cell at the end stage of a series of metabolic reactions within a pathway to produce energy (C. Brewer, 2017) as we can see and understand that the freshness of student cardiorespiratory freshness before the pandemic period and after the pandemic period is certainly different so that there will be a change from the freshness of student cardiorespiratory freshness.

\section{METHODS}

\section{Research Methods}

This research is a qualitative descriptive study, which is research conducted to answer problems about the state or condition as it is in the field in the phenomenon to be studied using the media of calculating numbers (Sugiono, 2016). The method used is a survey with data collection techniques using measurement tests. The test is a series of questions or exercises and other tools used to measure knowledge, intelligence, abilities or talents possessed by individuals or groups (Arikunto, 2013)

\section{Types of Research}

This type of research used in research is quantitative research.

\section{Research Instruments}

The research instrument is a measuring tool that supports the success of research to collect data. The instrument used to determine the cardiorespiratory freshness level of students is the multistage fitness test or the bleep test. This test has many advantages including it can be carried out in a field that is not so wide, test takers are easier in terms of supervision, and students can be tested together or in groups.

The multistage fitness test running research instrument used to measure the cardiorespiratory freshness level of this 
student has an instrument validity of 0.71 and a reliability of 0.521 .

\section{Data Collection Techniques}

The data collection techniques used for this study were as follows:

1. Observation, which requires the full presence of the researcher, and therefore social and emotional relationships need to be established between the researcher and the actor being observed. Also, the researcher is also assisted by two research members.

2. Observations, at this stage the researcher observes the symptoms that occur and finds problems in the research location

3. Tests, tests that are conducted are athletic physical ability tests

\section{Data Analysis Techniques}

Based on the type of research, this is a quantitative descriptive study with the following steps:

1. Add up the test scores

2. Analyze test results

3. Connecting with the table of physical fitness norms based on VO2Max and the category table will be able to determine the level of physical fitness.

\section{RESULT}

The results of the overall study of the cardiorespiratory freshness level of the 2018 National Education and Physical Education Center students at Nusa Cendana University: Descriptive analysis shows that the maximum value of the cardiorespiratory freshness level of the 2018 National Education and Physical Education Center students at Nusa Cendana University is 54. Meanwhile, the minimum score is 27.6. The average cardiorespiratory freshness level of students was 38.91. and standard deviation (SD) 6.63 .

Table 1. Frequency Distribution of Classification of Cardiorespiratory Freshness Levels of 2018 National Education Team for Physical Education at Nusa Cendana University.

\begin{tabular}{|c|c|c|c|}
\hline \multirow{2}{*}{$\begin{array}{c}\text { Interval } \\
\text { skor }\end{array}$} & \multirow[t]{2}{*}{ Klasifikasi } & \multicolumn{2}{|c|}{ Frekwensi } \\
\hline & & Absolut & presentase \\
\hline \multirow[t]{2}{*}{$<35$} & Sangat & 10 & $33,33 \%$ \\
\hline & Kurang & & \\
\hline $35-37$ & Kurang & 3 & $10 \%$ \\
\hline $38-44$ & Cukup baik & 10 & $33,33 \%$ \\
\hline $45-50$ & Baik & 5 & $16.66 \%$ \\
\hline $51-55$ & Baik sekali & 2 & $6,66 \%$ \\
\hline$>55$ & Istimewa & & $0 \%$ \\
\hline Jumlah & & 30 & 100 \\
\hline \multicolumn{4}{|c|}{ frekwensi } \\
\hline \multicolumn{4}{|l|}{$35,00 \%$} \\
\hline \multicolumn{4}{|l|}{$30,00 \%$} \\
\hline \multicolumn{4}{|l|}{$25,00 \%$} \\
\hline \multicolumn{4}{|l|}{$20,00 \%$} \\
\hline \multicolumn{4}{|l|}{$15,00 \%$} \\
\hline \multicolumn{4}{|l|}{$10,00 \%$} \\
\hline \multicolumn{4}{|l|}{$5,00 \%$} \\
\hline $0,00 \%$ & & & \\
\hline & $\begin{array}{ccc}<35 & 35- & 38 \\
& 37 & 44\end{array}$ & $\begin{array}{cc}45- & 51- \\
50 & 55\end{array}$ & $>55$ \\
\hline
\end{tabular}

Figure 1. Histogram of Frequency Distribution of Classification of Cardiorespiratory Freshness Levels of 2018 Physical Education and Health Education Students at Nusa Cendana University 


\section{DISCUSSION}

The purpose of this study is to see how the cardiorespiratory freshness of the 2018 class of physical education and health education students at Nusa Sandalwood University during the current Covid 19 pandemic by using a zoom application or other online application, in East Nusa Tenggara. So that it can be seen clearly whether Covid 19 reduces the level of cardiorespiration or increases the level of cardiorespiration of the 2018 class of physical education students at Nusa Sandalwood University.

The results of the classification of the data were 30 Penjaskesrek class 2018 Nusa Cendana University students who took the multistage fitness test to find out the level of cardiorespiratory freshness was in the very poor classification of 10 people with a percentage of $33.33 \%$, less classification of 3 people (10\%), Good enough classification 10 people (33.33\%), good classification 5 people (16.66\%), very good classification 2 people $(6.66 \%)$, and no students are in the special classification $(0 \%)$.

The relationship with the physical activities carried out by students both during learning and outside learning hours can be said to be lacking. This is also because the risk of COVID 19 is related to outdoor sports. Therefore, after a study was carried out to measure the cardiorespiratory freshness of the 2018 National Education and Physical Education Center students at Nusa Cendana University which was conducted online using a multistage fitness test or bleep test, the results showed that the level of cardiorespiratory freshness The 2018 Nusa Cendana University Penjaskesrek students are in a sufficient classification.

If you look at the same research, the focus of research on cardio respiration is certainly different. It can be understood that the research carried out during the pandemic period, of course, has a significant difference. If compared scientifically, of course, the cardiorespiratory fitness of students who were not during the pandemic, of course, they used face-to-face learning and their physical activities were carried out directly which could also be monitored. It is different from those who did this research with the same variables during the pandemic because using full elearning would be very difficult to monitor learning activities carried out online.

\section{CONCLUSION}

Based on the results of the data, the results of the research on the cardiorespiratory freshness level were obtained by measuring using a multistage fitness test or bleep test for the 2018 National Education and Physical Education Center students at Nusa Cendana University.

The cardiorespiratory level of physical education and health education students class 2018 varies according to classification. There are 10 people in the very poor classification with a percentage of $33.33 \%, 3$ people (10\%) lacking classification, good enough classification 10 people $(33.33 \%)$, good classification 5 people (16.66\%), very good classification 2 people $(6.66 \%)$, and no students are in 
the special classification (0\%). It was found that the cardiorespiratory freshness level of the 2018 National Education Team for Physical Education, Nusa Cendana University was classified as sufficient.

During the covid-19 pandemic this greatly affects physical activity. Aerobic exercise that is done is of course also risky if done outdoors. If done indoors, of course there are limited space. Limitations in research can also be understood that mass research cannot be carried out because it will increase the percentage of transmission.

The relationship with the physical activities carried out by students both during learning and outside learning hours can be said to be lacking. Things that can be developed in this research we can give a larger scale not only at the faculty level, also at the university level, even at the provincial level.

\section{REFERENCES}

Anderson, L., \& Glover, D. R. (2017). Building Character, Community, and a Growth Mindset in Physical Education: Activities That Promote Learning and Emotional and Social Development. Human Kinetics.

Arif, Y., Boleng, L. M., Babang, V. M. M. F., \& Saba, K. R. (2019). Pengaruh Keseimbangan, Daya Ledak Otot Tungkai, Dan Motivasi Berprestasi Dengan Kemampuan Tendangan Monthong Doliochagi (Vol. 3, Issue 3). https://doi.org/http://dx.doi.org/10.2388 7/ijerr.v2i3.21091.g13182

Arif, Y., Boleng, L. M., Maria, V., Flora, M., \& Saba, K. R. (2019). The Effect of Weight Training Using Inner-Load Outer-Load on the Process of
Developing Chest Muscles in Fitness Members in the City of Kupang. International Journal of Innovation, Creativity and Change, 5(3), 478-491. https://www.ijicc.net/images/Vol_5_Iss _3/28_Neolaka_P478_2019R.pdf

Arikunto, S. (2013). Prosedur penelitian atau pendekatan praktik. Cet XV.

Ayers, S. F., \& Sariscsany, M. J. (2011). Physical Education for Lifelong Fitness.

Brewer, C. (2017). athletic movement skills, Training for Sports Performance. Human Kinetics.

Brewer, H. (2018). Physical Activity and Health Promotion in the Early Years: Effective Strategies for Early Childhood Educators. In Springer (14th ed.). springer. https://doi.org/10.1007/978-3319-76006-3

Bridge, C. A., Ferreira Da Silva Santos, J., Chaabène, H., Pieter, W., \& Franchini, E. (2014). Physical and physiological profiles of Taekwondo athletes. In Sports Medicine (Vol. 44, Issue 6, pp. 713-733). https://doi.org/10.1007/s40279-0140159-9

Development, L. A., \& Coaching. (2012). Taekwondo for Life. National Coahing Certification Program.

Harold W. Kohl III, H. D. C. (2013). Educating the Student Body: Taking Physical Activity and Physical Education to School. In National Academies Press. National Academies Press. https://doi.org/10.17226/18314

Lynn, S. K., Noffal, G. J., \& Pamukoff, D. N. (2018). Biomechanics of resistance training. In Conditioning for Strength and Human Performance (pp. 96-123). Routledge.https://doi.org/10.4324/9781 315438450-6

Osler, S. (2019). Coronavirus Outbreak. Journal of Chemical Information and Modeling, 1-83.

Sugiyono. (2016). Metode Penelitan 
Kuantitatif, kualitatif dan R\&D.

Bandung: Alfabeta.

Sullivan, L. (2015). Health and Physical Education. In The SAGE Glossary of the Social and Behavioral Sciences. ontario. https://doi.org/10.4135/9781412972024 .n1169

Tinning, R. (2010). Pedagogy and Human Movement. Routledge. 